\title{
Effects of Non-Collagenous Proteins, TGF- $\beta 1$, and PDGF-BB on Viability and Proliferation of Dental Pulp Stem Cells
}

\author{
Fahimeh Sadat Tabatabaei ${ }^{1,2}$, Maryam Torshabi ${ }^{1,2}$ \\ 'Department of Dental Biomaterials, School of Dentistry, Shahid Beheshti University of Medical sciences, Tehran, Iran. \\ ${ }^{2}$ Department of Tissue Engineering, School of Advanced Technologies in Medicine, Shahid Beheshti University of Medical \\ Sciences, Tehran, Iran.
}

\author{
Corresponding Author: \\ Maryam Torshabi \\ Evin, 1983963113, Tehran \\ Iran \\ Phone: +982122173754 \\ Fax: +982122173754 \\ E-mail: maryam torshabi@yahoo.com / torshabi@sbmu.ac.ir
}

\begin{abstract}
Objectives: The dentin matrix servers as a reservoir of growth factors, sequestered during dentinogenesis. The aim of this study was to assess the viability and proliferation of dental pulp stem cells in the presence of dentin matrix-derived noncollagenous proteins and two growth factors; platelet-derived growth factor BB and transforming growth factor beta 1.

Material and Methods: The dental pulp cells were isolated and cultured. The dentin proteins were extracted and purified. The MTT assay was performed for assessment of cell viability and proliferation in the presence of different concentrations of dentin proteins and growth factors during $24-72 \mathrm{~h}$ post-treatment.

Results: The cells treated with $250 \mathrm{ng} / \mathrm{mL}$ dentin proteins had the best viability and proliferation ability in comparison with other concentrations $(\mathrm{P}<0.05)$. The MTT assay demonstrated that cells cultured with $5 \mathrm{ng} / \mathrm{mL}$ platelet-derived growth factor $\mathrm{BB}$ had the highest viability at each time point as compared to other groups $(\mathrm{P}<0.05)$. However, in presence of plateletderived growth factor BB alone and in combination with transforming growth factor beta 1 and dentin proteins $(10 \mathrm{ng} / \mathrm{mL})$, significant higher viability was seen at all time points $(\mathrm{P}<0.05)$. The least viability and proliferation at each growth factor concentration was seen in cells treated with combination of transforming growth factor beta 1 and dentin proteins at $72 \mathrm{~h}$ $(\mathrm{P}<0.05)$.

Conclusions: The results indicated that the triple combination of growth factors and matrix-derived non-collagenous proteins (especially at $10 \mathrm{ng} / \mathrm{mL}$ concentration) has mitogenic effect on dental pulp stem cells.
\end{abstract}

Keywords: dental pulp; dentin protein (non-collagenous); platelet-derived growth factor bb; transforming growth factor beta.

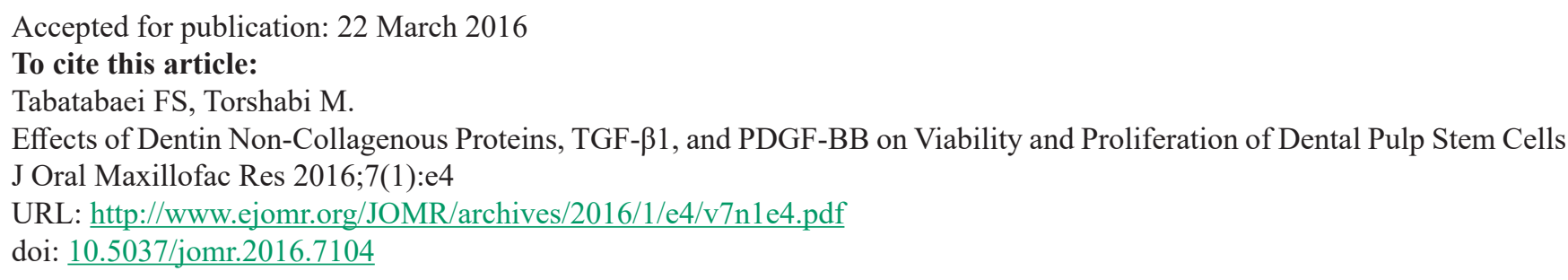




\section{INTRODUCTION}

Dental caries is a common disease in humans. In dentistry, defects have long been treated with durable dental materials, which all have a limited performance and eventually fail after a period of clinical service [1]. Pulp repair requires a sequence of cellular events resembling those involved in soft tissue wound healing. These events include chemotaxis, proliferation of mesenchymal cells at the site of injury and production of extracellular matrix. The mineralized reparative dentine, the ultimate evidence of pulp repair, is analogous to scar tissue formation in the connective tissues in other parts of the body [2] In the recent years, there has been a rising recognition that healing protocols for treatment of carious lesions are possible and clinicians no longer have to merely rely on surgical removal of the diseased tissue and placement of restorative materials [3]. Today, the use of biological molecules for the development of novel restorative treatment modalities in clinical dentistry is in sight [4]. These modalities have potential applications in unexposed cavity preparations for protection of the pulp against the deleterious effects of dental materials by increasing the residual dentin thickness through reactionary dentinogenesis. Also, these approaches may have potential applications in exposed pulp cases to restore the structural integrity of dentin by the induction of reparative dentinogenesis. Such biological approaches may also have indications for use in the severely compromised dental pulps to seal the root canal in endodontic therapy [].

The dentine matrix serves as a potential reservoir of growth factors such as platelet-derived growth factor $\mathrm{BB}$ (PDGF-BB), transforming growth factor beta 1 (TGF- $\beta 1$ ) and other bio-active molecules, sequestered during dentinogenesis. These factors may be released by bacterial acids or dental materials during caries episodes or restorative treatments, and may contribute to dentine repair or regeneration [5]. These molecules may have a role for potential use in dental therapy as bioactive agents for dentinpulp repair or tissue engineering purposes [ $[\underline{6}, \underline{7}]$. The non-collagenous matrix proteins may also serve as mediators of cell-matrix interactions, matrix maturation and mineralization [8]. Especially, the dentine matrix components released by EDTA etchants demonstrate significant morphogenetic activity and induce reparative dentinogenesis in vivo $[\underline{9}, \underline{10}]$. It is generally accepted that dentin noncollagenous proteins (DNCPs) are involved in the promotion and regulation of dentin mineralization [7].
Also, DNCPs, composed of glycoproteins, sialoproteins, phosphoroteins, proteoglycans and growth factors, can promote cell differentiation [11-17]. When a carious lesion develops, the matrix-bound bioactive molecules such as TGF- $\beta 1$ family members may be released from the dentin by the activity of bacterial plaque acids, diffuse through the dentin, and induce odontoblast-like cell differentiation of potential progenitor cells in the pulp [18].

Previous experimental studies have highlighted the interactions between dentin and surrounding cells; meanwhile evidence reveals that dentin molecules might function as regulatory signals for various mesenchymal stem cells to enhance the healing of injured pulp tissues [14]. A more thorough understanding of how these signalling pathways are functionally linked can greatly help design therapeutic strategies targeting dental pulp stem cells (DPSCs) in the dentin-pulp complex. Considering the confirmed presence of direct dentin-pulp cell contact, we anticipate that concentration of different growth factors in dentin matrix may play a pivotal role in proliferation of DPSCs during the first stage of pulp repair. Therefore, this study sought to assess the effects of dentin matrix proteins, TGF- $\beta 1$ and PDGFBB on cultured DPSCs to better elucidate the process of tissue repair in teeth.

\section{MATERIAL AND METHODS Materials}

Phosphate buffered saline (PBS), Fetal bovine serum (FBS), Trypsin-EDTA and Dulbecco's modified Eagle's medium (DMEM) were from Gibco (Paisley, UK). The Dimethylsulfoxide (DMSO), ethylenediaminetetraacetic acid (EDTA), phenylmethylsulfonyl fluoride (PMSF) and MTT and was from Sigma-Aldrich (Steinheim, Germany). Recombinant human PDGF-BB and TGF- $\beta 1$ were from PeproTech (Hamburg, Germany). All tissue culture plastic-wares were obtained from SPL Lifesciences (Gyeonggi-do, South Korea). All other reagents were of analytical grade.

\section{Isolation of dentine extracellular-matrix components}

DNCPs were isolated as explained by Smith with some modifications $[19,20]$. The extracted human teeth were obtained from the Oral Surgery Department at the School of Dentistry (Shahid Beheshti University of Medical Sciences) after obtaining informed patient consent. The teeth were stored in a saturated sodium chloride solution and then washed with water 
and air-dried. After soaking in ethanol for $20 \mathrm{~h}$, the teeth were air-dried again. The root surfaces were prepared by removing the soft tissue residues using a surgical scalpel. The pulp tissues were removed using a barbed broach and a dental probe. The enamel and cementum were then removed by drilling with a highspeed diamond bur under water cooling.

The remaining dentine was crushed into a fine powder using a percussion mill (Spex 6700 Freezer/Mill, Glen Creston Ltd., UK), cooled with dry ice and filtered through a $60 \mathrm{~mm}$ mesh sieve (VEB Metallweberei, Germany). Dentine matrix components were extracted from the powdered dentine using 10\% EDTA solution (pH of 7.2). The protease inhibitors namely $10 \mathrm{mM}$ $\mathrm{N}$-ethylmaleimide (NEM) and $5 \mathrm{mM}$ PMSF were also added to the solution.

Extractions were performed at $4{ }^{\circ} \mathrm{C}$ for 14 days. The demineralizing solution was changed every $48 \mathrm{~h}$ and the EDTA-soluble fraction in the supernatant was collected after centrifugation at $3000 \mathrm{rpm}$ for $10 \min \left(4{ }^{\circ} \mathrm{C}\right.$, Eppendorf, USA $)$. The combined EDTA-soluble fractions over the 14 day period were transferred to dialysis sacs (Sigma-Aldrich, Germany) and dialyzed exhaustively for 10 days against repeated changes of distilled water. The dialyzed extracts were lyophilized using a freeze dryer (Mini-Lyotrap, LTE Scientific Ltd, Oldham, UK).

\section{Cell culture}

The DPSCs were isolated from a healthy donor, cultured and expanded as previously described [21]. Briefly, the third molars intended for extraction served as the cell source. Dental pulp tissue was harvested from the sectioned teeth and cut into small pieces. It was then placed in a tissue culture flask. The explants were stored in DMEM containing $1 \%$ antibioticantimycotic and $10 \% \mathrm{FBS}$ at $37{ }^{\circ} \mathrm{C}$ in a humidified atmosphere with $5 \% \mathrm{CO}_{2}$ until proliferating cells became confluent. Then, the digested cells with $0.25 \%$ trypsin were cultured at a low-cell density. The fourth passage cells were used in the experiments.

\section{MTT assay}

To evaluate the proliferation potential and viability of DPSCs treated or untreated with DNCPs, TGF- $\beta 1$ and/or PDGF-BB, two phases were performed. In the first phase, different concentrations of DNCPs (25 $\mu \mathrm{g} / \mathrm{mL}, \quad 10 \mu \mathrm{g} / \mathrm{mL}, \quad 5 \mu \mathrm{g} / \mathrm{mL}, 250 \mu \mathrm{ng} / \mathrm{mL}$, $10 \mathrm{ng} / \mathrm{mL}$ and $5 \mathrm{ng} / \mathrm{mL}$ ) were added to DPSCs, while the control group contained only the regular medium (DMEM supplemented with $10 \%$ FBS and $1 \%$ antibiotic-antimycotic). In the second phase, the most efficient concentration of DNCPs resulted from phase one, was used to assess the behaviour of cells in presence of TGF- $\beta 1$, PDGF-BB and their combination with DNCPs. The concentrations of PDGF-BB and TGF- $\beta 1$ were selected based on previous studies, which indicated these to produce maximal stimulatory effect [22-24]. Ten groups were set:

- Group 1: 5 ng/mL TGF- $\beta 1$ was added to the regular medium.

- Group 2: $5 \mathrm{ng} / \mathrm{mL}$ PDGF-BB was added to the regular medium.

- Group 3: 250 ng/mL DNCPs + 5 ng/mL TGF- $\beta 1$ was added to the regular medium.

- Group 4: 250 ng/mL DNCPs + 5 ng/mL PDGF$\mathrm{BB}$ was added to the regular medium.

- Group 5: 250 ng/mL DNCPs +5 ng/mL TGF- $\beta 1$ $+5 \mathrm{ng} / \mathrm{mL}$ PDGF-BB was added to the regular medium.

- Group 6: $10 \mathrm{ng} / \mathrm{mL}$ TGF- $\beta 1$ was added to the regular medium.

- Group 7: $10 \mathrm{ng} / \mathrm{mL}$ PDGF-BB was added to the regular medium.

- Group 8: 250 ng/mL DNCPs + 10 ng/mL TGF- $\beta 1$ was added to the regular medium.

- Group 9: $250 \mathrm{ng} / \mathrm{mL}$ DNCPs $+10 \mathrm{ng} / \mathrm{mL}$ PDGF$\mathrm{BB}$ was added to the regular medium.

- Group 10: 250 ng/mL DNCPs + 10 ng/mL TGF- $\beta 1+10 \mathrm{ng} / \mathrm{mL}$ PDGF-BB was added to the regular medium.

The control group contained only the regular medium. Cells were plated at a density of $5 \times 10^{3}$ cells/well in 96-well plates and cultured in the regular medium for $24 \mathrm{~h}$. Next, they were exposed to different materials ( $\mathrm{n}=5$ in each group). The MTT assay was carried out at three different time points of 24,48 and 72 hours after exposure. Briefly, the medium containing 10\% MTT dye was added into each well at the end of experiments and cells were incubated for three hours. The supernatant in each well was then decanted and the insoluble formazan was eluted with dimethylsulfoxide (DMSO). Absorbance was read at $570 \mathrm{~nm}$ (620 nm reference) with a microplate ELISA reader (Anthos 2020, Austria). Cell viability was calculated as the ratio of values obtained for the treated cells and for untreated controls (as 100\%).

\section{Statistical analysis}

All quantitative tests were repeated three times and data were expressed as mean and standard deviation (M [SD]). For the comparison of viability, statistical significance was determined by one-way ANOVA (Tukey's post-hoc test) (GraphPad Prism software, version 6.01). Statistical significance level was defined at $\mathrm{P}=0.05$. 


\section{RESULTS}

\section{Cell viability and proliferation in the presence of different concentration of DNCPs}

As we can see in Figure 1, although there is no significant difference between different concentration of DNCPs in 24 and $48 \mathrm{~h}$ time intervals, the best proliferation could be seen in the presence of $250 \mathrm{ng} / \mathrm{mL}$ DNCPs in $72 \mathrm{~h}(134.5$ [17.7], $\mathrm{P}<0.05)$.

Cell viability and proliferation in the presence of DNCP, TGF-B1, PDGF-BB or combination of these factors

As seen in Figure 2A, DNCPs in presence of $5 \mathrm{ng} /$ $\mathrm{mL}$ TGF- $\beta 1$ showed a significantly higher viability (133.9 [15.4], $\mathrm{P}<0.05)$ at $24 \mathrm{~h}$ compared to the control group (Regular medium only). However, no significant differences were noted in this regard with the control group at 48 or $72 \mathrm{~h}(\mathrm{P}>0.05)$. Although combination of $5 \mathrm{ng} / \mathrm{mL}$ TGF- $\beta 1$ and $250 \mathrm{ng} / \mathrm{mL}$ DNCPs caused no significant change in cell viability compared to the control group at 24 and $48 \mathrm{~h}$, it significantly decreased cell viability at $72 \mathrm{~h}$ (71 [11.6], $\mathrm{P}<0.05)$. Also as time passed, the significant reduction $(\sim 20 \%)$ in cell viability (72 vs $24 \mathrm{~h}$ ) indicated that cell proliferation rate decreased during $24-72 \mathrm{~h}$ post-treatment in this group.

The MTT assay revealed that cells in presence of $5 \mathrm{ng} / \mathrm{mL}$ PDGF-BB showed a significant higher viability compared to the control group at all three time points ( $20 \%$ increase). Combination of $5 \mathrm{ng} / \mathrm{mL}$
PDGF-BB and $250 \mathrm{ng} / \mathrm{mL}$ DNCPs caused no significant change in comparison with the control group at any of the three time points $(\mathrm{P}>0.05)$.

Also, the combination of all three factors in the above-mentioned concentrations caused no significant change in comparison with the control group at any of the three time intervals $(\mathrm{P}>0.05)$.

As seen in Figure 2B, the pulp stem cells in the presence of $10 \mathrm{ng} / \mathrm{mL}$ TGF- $\beta 1$ showed a significant higher viability (123.1 [14.8], $\mathrm{P}<0.05)$ at $24 \mathrm{~h}$ compared to the control group (regular medium only). However, no significant difference with the control group was noted at 48 or $72 \mathrm{~h}$. Combination of $10 \mathrm{ng} / \mathrm{mL}$ TGF- $\beta 1$ and $250 \mathrm{ng} / \mathrm{mL}$ DNCPs did not cause a significant change in this regard in comparison with the control group at 24 h; however, it significantly decreased cell viability at 48 and $72 \mathrm{~h}(87.6$ [4.4] and 71 [11.6] respectively, $\mathrm{P}<0.05)$. On the other hand, the significant reduction $(\sim 40 \%)$ in cell viability $(72$ vs $24 \mathrm{~h})$ indicated that cell proliferation rate decreased during $24-72 \mathrm{~h}$ post-treatment in this group. Cell viability profile in the presence of $10 \mathrm{ng} / \mathrm{mL}$ PDGF-BB was almost similar to that in the presence of $5 \mathrm{ng} / \mathrm{mL}$ PDGF-BB; at this concentration $(10 \mathrm{ng} / \mathrm{mL})$, significant increase in cell viability was noted at all three time points compared to the control group $(\sim 120-140 \%, \mathrm{P}<0.05)$. The combination of $10 \mathrm{ng} / \mathrm{mL}$ PDGF-BB and $250 \mathrm{ng} / \mathrm{mL}$ DNCPs caused a significant increase in cell viability at 24 and $48 \mathrm{~h}$ (147.5 [24.8] and 120.9 [15.9] respectively, $\mathrm{P}<0.05)$, although there was no significant difference compared with the control group at $72 \mathrm{~h}$.

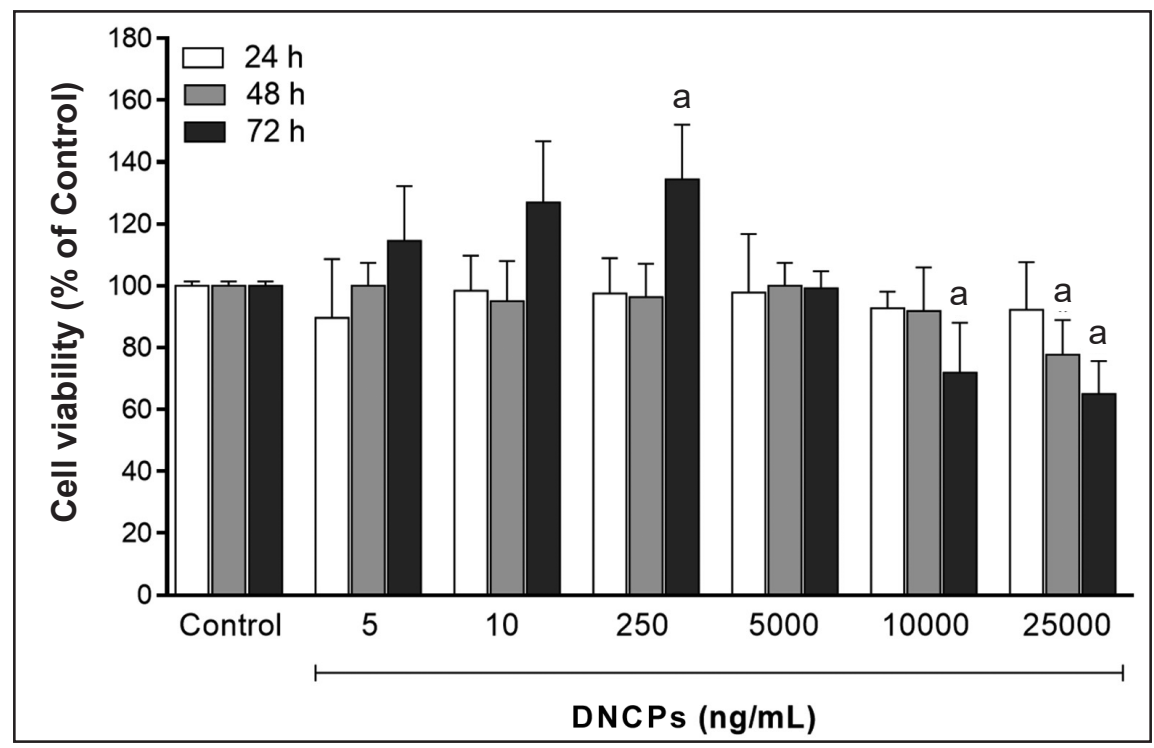

Figure 1. The effect of various concentration of DNCPs $(5-2500 \mathrm{ng} / \mathrm{mL})$ on cell viability in 3 time intervals assessed by MTT cell proliferation assay.

a Statistically significant difference at the level $\mathrm{P}<0.05$ (Tukey's post-hoc test) compared with the control group (regular medium without DNCPs; viability $100 \%)$. 


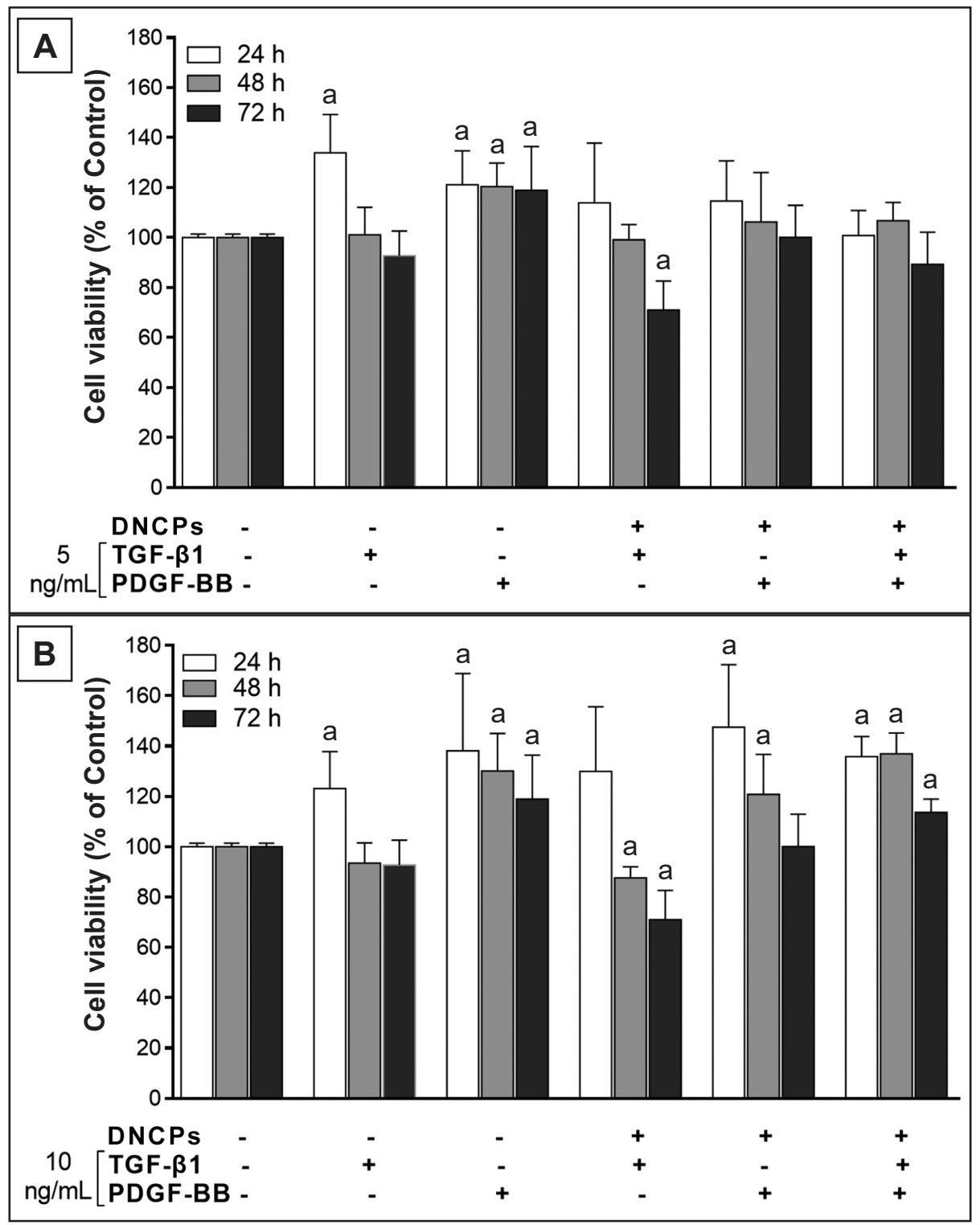

Figure 2. The effect of TGF- $\beta 1$ and PDGF-BB, and their combinations with DNCPs $(250 \mathrm{ng} / \mathrm{ml})$ on cell viability in 3 time intervals assessed by MTT cell proliferation assay. $\mathrm{A}=5 \mathrm{ng} / \mathrm{mL} ; \mathrm{B}=10 \mathrm{ng} / \mathrm{mL}$.

a Statistically significant difference at the level $\mathrm{P}<0.05$ (Tukey's post-hoc test) compared with the control group (regular medium without DNCPs, TGF- $\beta 1$ and PDGF-BB; viability $100 \%$ ).

Combining all three factors in the above-mentioned concentrations caused a significant increase in cell viability compared to the control group $(\sim 114-136 \%$, $\mathrm{P}<0.05)$.

\section{DISCUSSION}

The progenitor cells in the dental pulp, which are capable of being induced to differentiate into odontoblast-like cells for secreting the reparative dentine and forming a dentinal bridge remain elusive [25]. Gronthos et al. [26, 27] described a unique population of post-natal stem cells in the dental pulp that may be progenitors of odontoblastlike cells found at sites of dentine regeneration.
On the basis of direct dentine-pulp cell contact, we used DPSCs derived from extracted human teeth to better understand tissue repair in teeth.

Reparative dentine formation is a relatively complex event requiring the initial employment of appropriate progenitor cells from the pulp tissue followed by signalling of odontoblast-like cell differentiation $[28,29]$. Certainly, the bioactive signalling molecules released from the dentine matrix must be in suitable rate as recent studies demonstrated that increased concentrations of TGF- $\beta 1$ can cause unfavourable cellular effects including induction of apoptosis [30]. The release of matrix-associated molecules may be pivotal for modulation of bioactivity; since biological events may be modulated by the synergistic or antagonistic effects of growth factors 
and their interactions with the extracellular matrix [31]. The effects of TGF- $\beta 1$, fibroblast growth factor 8 (FGF8), and DNCPs on different stem cells have been confirmed in previous investigations $[\underline{11}, \underline{13}, \underline{30}]$. Until now, no study has compared the effects of TGF- $\beta 1$, PDGF-BB, DNCPs and their combinations on cell viability and proliferation. The results of the current study showed significant synergistic or antagonistic effects of these factors on DPSCs.

Different materials are used for the purpose of extraction of dentine extracellular-matrix components such as EDTA, calcium hydroxide and white and grey MTA (Mineral trioxide aggregate) [를 $\underline{33}]$. However, evidence indicates that the total yield of dentin matrix proteins is the greatest for EDTA [3234]. Accordingly, we used EDTA as the extracting medium.

We hypothesized that dentin matrix may act in conjunction with other factors to promote dentinogenesis by affecting the proliferation of small populations of DPSCs. In the current study, the first step indicated that DNCPs at some concentrations had no effect on viability of DPSCs but the concentration of $250 \mathrm{ng} / \mathrm{mL}$ promoted the proliferation of these cells. Ma et al. [15] demonstrated increased proliferation of human periodontal ligament stem cells (HPDLSCs) treated with DNCPs (at a concentration of $250 \mathrm{ng} / \mathrm{mL}$ ). In our study, DNCPs in concentrations of 10 and $25 \mu \mathrm{g} / \mathrm{mL}$ inhibited cell proliferation. Extracts of whole dentin extracellular matrix components have been shown to increase the proliferation of stem cells in vitro at relatively low concentrations; however, relatively high concentrations inhibit their proliferation $[\underline{35}, \underline{36}]$.

In the second step, we confirmed the antagonistic effects of some factors (DNCP + TGF- $\beta 1$ ) and synergistic effects of some others (DNCP + TGF- $\beta 1$ + PDGF-BB). The TGF- $\beta$ signalling pathway plays an important role in inhibiting proliferation while stimulating differentiation when appropriate [37]. Based on the result of our study, TGF- $\beta 1$ cause graduate decrease of cell viability. Accordingly, suppressive effects of TGF- $\beta 1$ on the growth of bovine and rat dental pulp cells have been shown [2]. Chan et al [38], also reported the poor proliferative capacity of pulp cells in presence of TGF- $\beta 1$ $(1-10 \mathrm{ng} / \mathrm{mL})$. The mechanism of anti-proliferative effects of TGF- $\beta$ signalling pathway is mediated via regulation of some proteins that drive the G1 phase of the cell cycle [39]. However, Fujii et al. [40] reported that TGF- $\beta 1$ stimulates the growth of periodontal ligament cells. Moreover, TGF- $\beta 1$ increases the cell proliferation and extracellular matrix production in culture of dental pulp tissue [41], and it's effect can be synergistically upregulated by fibroblast growth fatocr-2 (FGF2) [42]. In the current study, we demonstrated that DNCP + TGF- $\beta 1$ have greater deleterious effects on cell proliferation than TGF- $\beta 1$ alone. Deng et al. [11] have shown in their study that DNCPs + TGF- $\beta 1$ were capable of inducing functional differentiation of stem cells. Since, proliferation and differentiation have an inverse relationship, the synergistic effects of these two factors (DNCP + TGF- $\beta 1$ ) in our study might have ultimately led to stem cell differentiation (timedependent reduction in proliferation rate) rather than proliferation.

Based on our results, PDGF-BB in both concentrations had a stimulatory effect on cell proliferation. Previous experiments have shown that PDGF-BB enhances the proliferation of bone marrow mesenchymal stem cells in vitro [43]. Rutherford et al. [44] showed that separate addition of PDGF-BB and IGF-1 to cultured human dental pulp cells elicits a weak mitogenic response. But, the mitogenic effect of the combination of PDGF-BB and IGF-1 on cultured human dental pulp cells was found to be additive. However, in our study, the combination of PDGF-BB + DNCPs had no significant effect on cell proliferation; although the combination of all three factors (TGF- $\beta 1+$ PDGF-BB + DNCPs) in $10 \mathrm{ng} / \mathrm{mL}$ concentration had a significant effect on cell proliferation.

The growth factors are costly. Moreover, several doses might be needed in order to achieve a therapeutic effect. In the current study, we demonstrated that DNCPs can increase the proliferation rate of DPSCs. These findings provide convincing evidence and useful data supporting the use of dentin matrix as a potent tool to induce tissue repair and regeneration. Besides, DNCPs are achievable in great amounts from the human third molars and premolars scheduled for extraction due to orthodontic reasons or also from the dentin of developing teeth in animals. So, in comparison with other matrix proteins available in the market, DNCPs may have an advantage in that they are easily supplied. We comprehensively characterized the effects of PDGF-BB, DNCPs and TGF- $\beta 1$ on DPSC proliferation. But, the mechanism of the respective effect and the relationship of different matrix proteins should be further assessed in future studies. Future work should also address the effects of the aforementioned bioactive molecules on cell differentiation. 


\section{CONCLUSIONS}

In conclusion, this study demonstrated that dentin noncollagenous proteins can efficiently stimulate the proliferation of dental pulp stem cells. The results showed that when dental pulp stem cells were treated with $10 \mathrm{ng} / \mathrm{mL}$ concentration of transforming growth factor beta $1+$ platelet-derived growth factor $\mathrm{BB}+$ dentin noncollagenous proteins, cell viability and proliferation increased, while dentin noncollagenous proteins + transforming growth factor beta 1 inhibited cell proliferation. This suggests that the combination of transforming growth factor beta $1+$ plateletderived growth factor $\mathrm{BB}+$ dentin noncollagenous proteins at some concentrations serves as a mitogen for dental pulp stem cells' proliferation.

\section{ACKNOWLEDGMENTS AND DISCLOSURE STATEMENTS}

No potential conflict of interest relevant to this article was reported.

\section{REFERNCES}

1. Smith AJ, Lumley PJ, Tomson PL, Cooper PR. Dental regeneration and materials: a partnership. Clin Oral Investig. 2008 Jun;12(2):103-8. [Medline: 18270756] [doi: 10.1007/s00784-008-0189-5]

2. Nakashima M. The effects of growth factors on DNA synthesis, proteoglycan synthesis and alkaline phosphatase activity in bovine dental pulp cells. Arch Oral Biol. 1992 Mar;37(3):231-6. [Medline: 1375023] [doi: 10.1016/0003-9969(92)90093-N]

3. Chai Y, Slavkin HC. Prospects for tooth regeneration in the 21st century: a perspective. Microsc Res Tech. 2003 Apr 1;60(5):469-79. [Medline: 12619122] [doi: 10.1002/jemt.10287]

4. Tziafas D. The future role of a molecular approach to pulp-dentinal regeneration. Caries Res. 2004 May-Jun;38(3):314-20. [Medline: 15153705$]$ [doi: $\underline{10.1159 / 000077771]}$

5. Linde A. Dentin matrix proteins: composition and possible functions in calcification. Anat Rec. 1989 Jun;224(2):154-66. [Medline: 2672882] [doi: 10.1002/ar.1092240206]

6. Lesot H, Smith A, Tziafas D, Begue-Kirn C, Cassidy N, Ruch J. Biologically active molecules and dental tissue repair: a comparative review of reactionary and reparative dentinogenesis with the induction of odontoblast differentiation in vitro. Cell Mater. 1994;4(3):199-218.

7. Smith AJ, Lesot $\mathrm{H}$. Induction and regulation of crown dentinogenesis: embryonic events as a template for dental tissue repair? Crit Rev Oral Biol Med. 2001;12(5):425-37. [Medline: 12002824] [doi: 10.1177/10454411010120050501]

8. Boskey AL. Matrix proteins and mineralization: an overview. Connect Tissue Res. 1996;35(1-4):357-63. [Medline: 9084675] [doi: 10.3109/03008209609029212]

9. Smith AJ, Tobias RS, Plant CG, Browne RM, Lesot H, Ruch JV. In vivo morphogenetic activity of dentine matrix proteins. J Biol Buccale. 1990 Jun;18(2):123-9. [Medline: 2211578]

10. Tziafas D, Alvanou A, Panagiotakopoulos N, Smith AJ, Lesot H, Komnenou A, Ruch JV. Induction of odontoblastlike cell differentiation in dog dental pulps after in vivo implantation of dentine matrix components. Arch Oral Biol. 1995 Oct;40(10):883-93. [Medline: 8526798] [doi: 10.1016/0003-9969(95)00069-2]

11. Deng M, Shi J, Smith AJ, Jin Y. Effects of transforming growth factor betal (TGFbeta-1) and dentin noncollagenous proteins (DNCP) on human embryonic ectomesenchymal cells in a three-dimensional culture system. Arch Oral Biol. 2005 Nov;50(11):937-45. Erratum in: Arch Oral Biol. 2008 Jun;53(6):590. [Medline: 15871903] [doi: 10.1016/j.archoralbio.2005.03.005]

12. Goldberg M, Smith A. Cells and extracellular matrices of dentin and pulp: a biological basis for repair and tissue engineering. Crit Rev Oral Biol Med. 2004 Jan 1;15(1):13-27. [Medline: 14761897] [doi: 10.1177/154411130401500103]

13. Jiang HB, Tian WD, Liu LK, Xu Y. In vitro odontoblast-like cell differentiation of cranial neural crest cells induced by fibroblast growth factor 8 and dentin non-collagen proteins. Cell Biol Int. 2008 Jun;32(6):671-8. [Medline: 18339562] [doi: 10.1016/j.cellbi.2008.01.293]

14. iu J, Jin T, Ritchie HH, Smith AJ, Clarkson BH. In vitro differentiation and mineralization of human dental pulp cells induced by dentin extract. In Vitro Cell Dev Biol Anim. 2005 Jul-Aug;41(7):232-8. [Medline: 16223338] [doi: $10.1290 / 0502014.1]$

15. Ma Z, Li S, Song Y, Tang L, Ma D, Liu B, Jin Y. The biological effect of dentin noncollagenous proteins (DNCPs) on the human periodontal ligament stem cells (HPDLSCs) in vitro and in vivo. Tissue Eng Part A. 2008 Dec;14(12):2059-68. [Medline: 18939934] [doi: 10.1089/ten.tea.2008.0021]

16. Kim HS, Lee DS, Lee JH, Kang MS, Lee NR, Kim HJ, Ko JS, Cho MI, Park JC. The effect of odontoblast conditioned media and dentin non-collagenous proteins on the differentiation and mineralization of cementoblasts in vitro. Arch Oral Biol. 2009 Jan;54(1):71-9. [Medline: 19006784] [doi: 10.1016/j.archoralbio.2008.09.011] 
17. Wu J, Jin F, Tang L, Yu J, Xu L, Yang Z, Wu G, Duan Y, Jin Y. Dentin non-collagenous proteins (dNCPs) can stimulate dental follicle cells to differentiate into cementoblast lineages. Biol Cell. 2008 May;100(5):291-302. [Medline: 18042041$]$ [doi: 10.1042/BC20070092]

18. Smith AJ. Vitality of the dentin-pulp complex in health and disease: growth factors as key mediators. J Dent Educ. 2003 Jun;67(6):678-89. [Medline: 12856968]

19. Smith AJ, Leaver AG. Non-collagenous components of the organic matrix of rabbit incisor dentine. Arch Oral Biol. 1979;24(6):449-54. [Medline: 118725] [doi: 10.1016/0003-9969(79)90007-4]

20. Tabatabaei FS, Ai J, Jafarzadeh Kashi TS, Khazaei M, Kajbafzadeh AM, Ghanbari Z. Effect of dentine matrix proteins on human endometrial adult stem-like cells: in vitro regeneration of odontoblasts cells. Arch Oral Biol. 2013 Jul;58(7):871-9. [Medline: 23465411] [doi: 10.1016/j.archoralbio.2013.01.013]

21. Tabatabaei FS, Jazayeri M, Ghahari P, Haghighipour N. Effects of equiaxial strain on the differentiation of dental pulp stem cells without using biochemical reagents. Mol Cell Biomech. 2014 Sep;11(3):209-20. [Medline: 25831861]

22. Cassiede P, Dennis JE, Ma F, Caplan AI. Osteochondrogenic potential of marrow mesenchymal progenitor cells exposed to TGF-beta 1 or PDGF-BB as assayed in vivo and in vitro. J Bone Miner Res. 1996 Sep;11(9):1264-73. [Medline: $\underline{8664901]}$ [doi: 10.1002/jbmr.5650110911]

23. Denholm IA, Moule AJ, Bartold PM. The behaviour and proliferation of human dental pulp cell strains in vitro, and their response to the application of platelet-derived growth factor-BB and insulin-like growth factor-1. Int Endod J. 1998 Jul;31(4):251-8. [Medline: 9823114] [doi: 10.1046/j.1365-2591.1998.00161.x]

24. Nasu K, Nishida M, Matsumoto H, Bing S, Inoue C, Kawano Y, Miyakawa I. Regulation of proliferation, motility, and contractivity of cultured human endometrial stromal cells by transforming growth factor-beta isoforms. Fertil Steril. 2005 Oct;84 Suppl 2:1114-23. [Medline: 16210002] [doi: 10.1016/j.fertnstert.2005.02.055]

25. Sloan AJ, Smith AJ. Stem cells and the dental pulp: potential roles in dentine regeneration and repair. Oral Dis. 2007 Mar;13(2):151-7. [Medline: 17305615] [doi: 10.1111/j.1601-0825.2006.01346.x]

26. Gronthos S, Brahim J, Li W, Fisher LW, Cherman N, Boyde A, DenBesten P, Robey PG, Shi S. Stem cell properties of human dental pulp stem cells. J Dent Res. 2002 Aug;81(8):531-5. [Medline: 12147742] [doi: 10.1177/154405910208100806]

27. Gronthos S, Mankani M, Brahim J, Robey PG, Shi S. Postnatal human dental pulp stem cells (DPSCs) in vitro and in vivo. Proc Natl Acad Sci U S A. 2000 Dec 5;97(25):13625-30. [Medline: 11087820] [PMC free article: 17626] [doi: 10.1073/pnas.240309797]

28. Smith AJ. Pulpal responses to caries and dental repair. Caries Res. 2002 Jul-Aug;36(4):223-32. [Medline: 12218270] [doi: $10.1159 / 000063930]$

29. Téclès O, Laurent P, Zygouritsas S, Burger AS, Camps J, Dejou J, About I. Activation of human dental pulp progenitor/stem cells in response to odontoblast injury. Arch Oral Biol. 2005 Feb;50(2):103-8. [Medline: 15721135] [doi: 10.1016/j.archoralbio.2004.11.009]

30. Smith A, Patel M, Graham L, Sloan A, Cooper P. Dentine regeneration: key roles for stem cells and molecular signalling. Oral Biosci Med. 2005;2(2/3):127-32.

31. Smith AJ, Matthews JB, Hall RC. Transforming growth factor-beta1 (TGF-beta1) in dentine matrix. Ligand activation and receptor expression. Eur J Oral Sci. 1998 Jan;106 Suppl 1:179-84. [Medline: 9541223] [doi: 10.1111/j.1600-0722.1998.tb02173.x]

32. Graham L, Cooper PR, Cassidy N, Nor JE, Sloan AJ, Smith AJ. The effect of calcium hydroxide on solubilisation of bio-active dentine matrix components. Biomaterials. 2006 May;27(14):2865-73. [Medline: 16427123] [doi: 10.1016/j.biomaterials.2005.12.020]

33. Tomson PL, Grover LM, Lumley PJ, Sloan AJ, Smith AJ, Cooper PR. Dissolution of bio-active dentine matrix components by mineral trioxide aggregate. J Dent. 2007 Aug;35(8):636-42. Epub 2007 Jun 12. [Medline: 17566626] [doi: 10.1016/j.jdent.2007.04.008]

34. Smith AJ, Leaver AG. Distribution of the EDTA-soluble non-collagenous organic matrix components of rabbit incisor dentine. Arch Oral Biol. 1981;26(8):643-9. [Medline: 6797393] [doi: 10.1016/0003-9969(81)90160-6]

35. Musson DS, McLachlan JL, Sloan AJ, Smith AJ, Cooper PR. Adrenomedullin is expressed during rodent dental tissue development and promotes cell growth and mineralization. Biol Cell. 2010 Jan 6;102(3):145-57. [Medline: 19828015] [doi: $10.1042 / \mathrm{BC} 20090122]$

36. Zhang R, Cooper PR, Smith G, Nör JE, Smith AJ. Angiogenic activity of dentin matrix components. J Endod. 2011 Jan;37(1):26-30. [Medline: 21146071] [doi: 10.1016/j.joen.2010.08.042]

37. Dong M, Blobe GC. Role of transforming growth factor-beta in hematologic malignancies. Blood. 2006 Jun 15;107(12):4589-96. [Medline: 16484590] [PMC free article: 1895802] [doi: 10.1182/blood-2005-10-4169]

38. Chan CP, Lan WH, Chang MC, Chen YJ, Lan WC, Chang HH, Jeng JH. Effects of TGF-beta s on the growth, collagen synthesis and collagen lattice contraction of human dental pulp fibroblasts in vitro. Arch Oral Biol. 2005 May;50(5): 469-79. [Medline: 15777529] [doi: 10.1016/j.archoralbio.2004.10.005]

39. Massagué J, Blain SW, Lo RS. TGFbeta signaling in growth control, cancer, and heritable disorders. Cell. 2000 Oct 13;103(2):295-309. [Medline: 11057902] [doi: 10.1016/S0092-8674(00)00121-5] 
40. Fujii S, Maeda H, Tomokiyo A, Monnouchi S, Hori K, Wada N, Akamine A. Effects of TGF- $\beta 1$ on the proliferation and differentiation of human periodontal ligament cells and a human periodontal ligament stem/progenitor cell line. Cell Tissue Res. 2010 Nov;342(2):233-42. [Medline: 20931341] [doi: 10.1007/s00441-010-1037-x]

41. Melin M, Joffre-Romeas A, Farges JC, Couble ML, Magloire H, Bleicher F. Effects of TGFbeta1 on dental pulp cells in cultured human tooth slices. J Dent Res. 2000;79(9):1689-96. [Medline: 11023265] [doi: 10.1177/00220345000790090901]

42. He H, Yu J, Liu Y, Lu S, Liu H, Shi J, Jin Y. Effects of FGF2 and TGFbeta1 on the differentiation of human dental pulp stem cells in vitro. Cell Biol Int. 2008 Jul;32(7):827-34. [Medline: 18442933] [doi: 10.1016/j.cellbi.2008.03.013]

43. Lucarelli E, Beccheroni A, Donati D, Sangiorgi L, Cenacchi A, Del Vento AM, Meotti C, Bertoja AZ, Giardino R, Fornasari PM, Mercuri M, Picci P. Platelet-derived growth factors enhance proliferation of human stromal stem cells. Biomaterials. 2003 Aug;24(18):3095-100. [Medline: 12895582] [doi: 10.1016/S0142-9612(03)00114-5]

44. Rutherford RB, Niekrash CE, Kennedy JE, Charette MF. Platelet-derived and insulin-like growth factors stimulate regeneration of periodontal attachment in monkeys. J Periodontal Res. 1992 Jul;27(4 Pt 1):285-90. [Medline: 1640350] [doi: 10.1111/j.1600-0765.1992.tb01679.x]

\section{To cite this article:}

Tabatabaei FS, Torshabi M.

Effects of Dentin Non-Collagenous Proteins, TGF- $\beta 1$, and PDGF-BB on Viability and Proliferation of Dental Pulp Stem Cells J Oral Maxillofac Res 2016;7(1):e4

URL: http://www.ejomr.org/JOMR/archives/2016/1/e4/v7n1e4.pdf

doi: $10.5037 /$ jomr.2016.7104

Copyright (C) Tabatabaei FS, Torshabi M. Published in the JOURNAL OF ORAL \& MAXILLOFACIAL RESEARCH (http://www.ejomr.org), 31 March 2016.

This is an open-access article, first published in the JOURNAL OF ORAL \& MAXILLOFACIAL RESEARCH, distributed under the terms of the Creative Commons Attribution-Noncommercial-No Derivative Works 3.0 Unported License, which permits unrestricted non-commercial use, distribution, and reproduction in any medium, provided the original work and is properly cited. The copyright, license information and link to the original publication on (http://www.ejomr.org) must be included. 